\title{
Performance and egg quality of laying hens fed different dietary levels of cashew nut shell liquid
}

\author{
N.M. Braz ${ }^{1}$, E.R. Freitas ${ }^{1 \#}$, M.T.S. Trevisan ${ }^{2}$, R.P.R. Salles ${ }^{1}$, C.E.B. Cruz ${ }^{1}$, N.N.P. Farias ${ }^{1}$ \\ \& P.H. Watanabe ${ }^{1}$ \\ ${ }^{1}$ Federal University of Ceará/CCA - Department of Animal Science, Av. Mister Hull, \\ 2.977 - 60021-970 - Fortaleza, CE - Brazil \\ ${ }^{2}$ Federal University of Ceará/CCA - Department of Organic and Inorganic Chemistry, Av. Mister Hull, \\ 2.977 - 60021-970 - Fortaleza, CE - Brazil
}

(Received 18 September 2017; Accepted 26 February 2019; First published online 8 June 2019)

\author{
Copyright resides with the authors in terms of the Creative Commons Attribution 4.0 South African License. \\ See: http://creativecommons.org/licenses/by/4.0/za \\ Condition of use: The user may copy, distribute, transmit and adapt the work, but must recognize the authors and \\ the South African Journal of Animal Science.
}

\begin{abstract}
Organic acids have stood out as alternatives to antibiotic growth promoters, especially those extracted from plants, such as anacardic acid, which is present in cashew nut shell liquid (CNSL). This study evaluates the effects of CNSL as a source of anacardic acid in diets of laying hens on performance, egg quality, lipid stability of yolk and microbiological analysis of excreta. A total of 216 commercial Hisex White laying hens were housed in cages and distributed in a completely randomized design with six treatments and six replicates of six birds per treatment. Treatments consisted of a diet without antibiotic growth promoter (AGP); diet with AGP (Halquinol $60 \%$ at $0.1 \mathrm{~g} / \mathrm{kg}$ and Enramycin $8 \%$ at $0.1 \mathrm{~g} / \mathrm{kg}$ ); and four diets without AGP and with the inclusion of 2.5, 5.0, 7.5 and $10.0 \mathrm{~g} / \mathrm{kg}$ CNSL. No effects of dietary addition of AGP and CNSL were observed in bird performance and external quality of eggs. A quadratic effect was observed for lipid oxidation in egg yolk, the minimum value of which was found at $5.8 \mathrm{~g} / \mathrm{kg}$ CNSL. There were no significant effects of treatments on total mesophilic, total coliform and thermotolerant coliform counts on excreta. In conclusion, adding up to $10.0 \mathrm{~g} / \mathrm{kg}$ of CNSL as source of anacardic acid in laying hen diet did not influence performance or egg quality, but the addition from $7.5 \mathrm{~g} / \mathrm{kg}$ of CNSL upwards reduced lipid oxidation and improved the yolk colour.
\end{abstract}

\section{Keywords: Anacardium occidentale, lipid oxidation, natural antioxidant, organic acid}

\#Corresponding author: ednardo@ufc.br

\section{Introduction}

For many years antibiotic additives have been the main form of controlling bacterial diseases on poultry farms. However, in view of the removal of antibiotics from poultry diets in various parts of the world, interest in researching alternatives to maintain the performance of birds and control the growth of harmful enteric bacteria has increased. In this context, organic acids stood out as possible alternatives to antibiotics, especially those extracted from plants, such as anacardic acid, which is present in cashew nut shell liquid.

Cashew nut shell liquid (CNSL) is a dark fluid extract that represents about $25 \%$ of cashew nut weight, and is one of the richest sources of isoprenoid phenolic lipids of natural origin (Mazzetto et al., 2009). Approximately $90 \%$ of CNSL consists of anacardic acid (a derivative of salicylic acid) and alkylresorcinols (cardols and cardanols), cardol being the main active compound of CNSL. Himejima \& Kubo (1991) and Muniz et al. (2006) demonstrated that anacardic acids have a beneficial effect against microorganisms, including gram-positive and gram-negative bacteria, yeasts and fungi. Addressing their antioxidant activity, Toyomizu et al. (2000) stated that anacardic acids are associated with the prevention of oxidative damage to liver mitochondria in rats. Trevisan et al. (2006) suggested that this acid contains three double bonds in the alkyl side-chain, which confer greater antioxidant and enzyme inhibition capacity. Moreover, the presence of the phytyl side-chain anacardic acid provides the potential to inhibit the generation of superoxide anion.

In broilers, Toyomizu et al. (2003) demonstrated the beneficial effect of anacardic acid on the prevention of injuries caused by coccidiosis. López et al. (2012) reported that the addition of CNSL to diets at 
the level of $0.40 \mathrm{~mL} / \mathrm{kg}$ provided a similar productive performance to that obtained with virginiamycin as growth promoter and reduced the concentration of Escherichia coli in the intestinal content. However, Odunsi \& Oyewole (1996) found that the addition of CNSL at levels above $1 \%$ to the diet of broilers impaired their performance. Nevertheless, the viability of use and the effects of this organic acid on productive performance of laying hens are not known. Thus, the objective of this study was to evaluate the effects of including various levels of CNSL in laying hen diets on performance, egg quality, lipid stability of yolk and microbiological analysis of excreta.

\section{Material and Methods}

The experimental procedures followed the protocols approved by Ethics Committee on Animal Research (CEPA 23/2013) of Federal University of Ceará, Brazil.

For the experiment, a total of 216 commercial Hisex White laying hens at 40 weeks old were housed in galvanized wire cages $\left(0.12 \mathrm{~m}^{2}\right)$ at the density of two birds per cage. The birds were distributed in a completely randomized design with six treatments and six replicates of six birds per treatment. The treatments consisted of T1: negative control (diet without antibiotic growth promoter (AGP)); T2: positive control (diet with AGP (Halquinol $60 \%$ at $0.1 \mathrm{~g} / \mathrm{kg}$ and Enramycin $8 \%$ at $0.1 \mathrm{~g} / \mathrm{kg}$ )); T3: diet with addition of $2.5 \mathrm{~g} / \mathrm{kg}$ of the CNSL, without AGP; T4: diet with $5.0 \mathrm{~g} / \mathrm{kg}$ of CNSL, without AGP; T5: diet with $7.5 \mathrm{~g} / \mathrm{kg}$ of CNSL, without AGP; and T6: diet with $10.0 \mathrm{~g} / \mathrm{kg}$ of CNSL, without AGP.

The experimental diets (Table 1) were isonutritive and isoenergetic, formulated according to strain recommendations (Hisex, no date). To obtain the CNSL, cashew nuts were heated in an oven at $175{ }^{\circ} \mathrm{C}$ for $45 \mathrm{~min}$ to release it (Trevisan et al., 2006). One hundred grams of nut yielded $30 \mathrm{~g}$ CNSL. A sample of CNSL was taken to the laboratory of Organic and Inorganic Chemistry Department of Federal University of Ceará for analysis of the compounds by high performance liquid chromatography (HPLC). The CNSL composition was $50 \%$ anacardic acid, $30 \%$ cardanol and $20 \%$ cardol. The CNSL was added to the treatments in liquid form by mixing with soybean oil.

During the experimental period of 105 days, the birds received feed and water ad libitum, with 16 hours of daily lighting. Feeders were refilled twice daily at 08:00 and 17:00. The temperature and relative humidity of the air inside the shed were measured daily with a maximum and minimum thermometer and a psychrometer, respectively. At the end of the experiment, the mean values obtained for minimum and maximum temperatures and relative humidity of the air in the shed were $26.82 \pm 1.56{ }^{\circ} \mathrm{C}, 30.33 \pm 1.40{ }^{\circ} \mathrm{C}$, and $70 \%$, respectively.

These performance variables were evaluated, namely feed intake (g), egg production (\%), egg weight (g), mass of eggs (g/day) and feed conversion ratio $(\mathrm{g} / \mathrm{g})$. Feed intake was calculated as the difference between the amount of feed supplied and the leftovers at the end of each period. Egg production was recorded daily per cage, and the laying percentages were calculated at the end of each period. The average egg weight $(\mathrm{g})$ was determined by dividing the total weight of the collected eggs by the number of eggs laid per replicate. The eggs were weighed once weekly on a digital precision scale $(0.01 \mathrm{~g})$. Egg mass was calculated by multiplying the average egg weight by the laying percentage. The feed conversion ratio was calculated based on feed intake and egg production data.

To evaluate the egg quality weekly, over the experimental period all eggs from each replicate were collected, identified, and evaluated for these characteristics: percentages of yolk, albumen, and shell, Haugh unit (HU), specific density, shell thickness and yolk colour. For the analyses of quality, three eggs were randomly selected per plot, avoiding broken, cracked and dirty eggs. Initially, the specific gravity (SG) of the eggs was determined, in which the egg weighing system was assembled on an electronic scale $(0.01 \mathrm{~g})$ to weigh the egg in air and in water. The weight values were recorded to calculate the SG by the following equation:

$$
S G=W A(W W \times F),
$$

where: $W A=$ egg weight in air

WW $=$ egg weight in water

$\mathrm{F}=$ temperature correction factor

After determining the SG, the eggs were cracked onto a glass surface to determine the albumen height, by using a depth micrometre. The albumen height and egg weight data were utilized in the calculation of $\mathrm{HU}$, by the following equation:

$$
\mathrm{HU}=100 \log \left(\mathrm{H}+7.57-1.7 \mathrm{~W}^{0.37}\right),
$$


where: $\mathrm{H}$ is the albumen height $(\mathrm{mm})$

$\mathrm{W}$ is the egg weight $(\mathrm{g})$.

Table 1 Ingredients and chemical composition of diets with or without antibiotic growth promoter and increasing levels of cashew nut shell liquid

\begin{tabular}{|c|c|c|c|c|c|c|}
\hline \multirow{2}{*}{ Ingredients } & \multirow{2}{*}{$\begin{array}{c}\text { Control } \\
\text { without AGP }\end{array}$} & \multirow{2}{*}{$\begin{array}{c}\text { Control } \\
\text { with AGP }\end{array}$} & \multicolumn{4}{|c|}{ Cashew nut shell liquid levels ( $\mathrm{g} / \mathrm{kg})$} \\
\hline & & & 2.5 & 5.0 & 7.5 & 10.0 \\
\hline Corn & 614.0 & 614.0 & 614.0 & 614.0 & 614.0 & 614.0 \\
\hline Soybean meal (45 \% CP) & 261.5 & 261.5 & 261.5 & 261.5 & 261.5 & 261.5 \\
\hline Soybean oil & 3.1 & 3.1 & 3.1 & 3.1 & 3.1 & 3.1 \\
\hline Limestone & 87.9 & 87.9 & 87.9 & 87.9 & 87.9 & 87.9 \\
\hline Dicalcium phosphate & 17.0 & 17.0 & 17.0 & 17.0 & 17.0 & 17.0 \\
\hline DL-methionine $99 \%$ & 1.3 & 1.3 & 1.3 & 1.3 & 1.3 & 1.3 \\
\hline Vitamin supplement ${ }^{1}$ & 0.5 & 0.5 & 0.5 & 0.5 & 0.5 & 0.5 \\
\hline Mineral supplement² & 1.0 & 1.0 & 1.0 & 1.0 & 1.0 & 1.0 \\
\hline Salt & 3.7 & 3.7 & 3.7 & 3.7 & 3.7 & 3.7 \\
\hline Inert (washed sand) & 10.0 & 9.7 & 7.5 & 5.0 & 2.5 & 0.0 \\
\hline Halquinol $60 \%$ & 0.0 & 0.1 & 0.0 & 0.0 & 0.0 & 0.0 \\
\hline Enramycin 8\% & 0.0 & 0.1 & 0.0 & 0.0 & 0.0 & 0.0 \\
\hline Antioxidant ${ }^{3}$ & 0.0 & 0.1 & 0.0 & 0.0 & 0.0 & 0.0 \\
\hline CNSL & 0.0 & 0.0 & 2.5 & 5.0 & 7.5 & 10.0 \\
\hline \multicolumn{7}{|c|}{ Calculated chemical composition } \\
\hline Metabolizable energy (MJ/kg) & 11.34 & 11.34 & 11.34 & 11.34 & 11.34 & 11.34 \\
\hline Crude protein $(\mathrm{g} / \mathrm{kg})$ & 170.0 & 170.0 & 170.0 & 170.0 & 170.0 & 170.0 \\
\hline Calcium (g/kg) & 39.0 & 39.0 & 39.0 & 39.0 & 39.0 & 39.0 \\
\hline Available phosphorus (g/kg) & 4.1 & 4.1 & 4.1 & 4.1 & 4.1 & 4.1 \\
\hline Sodium (g/kg) & 1.8 & 1.8 & 1.8 & 1.8 & 1.8 & 1.8 \\
\hline Lysine (g/kg) & 8.7 & 8.7 & 8.7 & 8.7 & 8.7 & 8.7 \\
\hline Methionine (g/kg) & 4.0 & 4.0 & 4.0 & 4.0 & 4.0 & 4.0 \\
\hline Methionine+cystine (g/kg) & 6.8 & 6.8 & 6.8 & 6.8 & 6.8 & 6.8 \\
\hline Threonine $(\mathrm{g} / \mathrm{kg})$ & 6.6 & 6.6 & 6.6 & 6.6 & 6.6 & 6.6 \\
\hline Tryptophan (g/kg) & 2.1 & 2.1 & 2.1 & 2.1 & 2.1 & 2.1 \\
\hline
\end{tabular}

${ }_{1}$ Warrant level per kg: vitamin A: 20000000 Ul; vitamin $\mathrm{D}_{3}: 7000000 \mathrm{UI}$; vitamin E: 80000 mg; vitamin $\mathrm{K}_{3}$ (Menadiona): $4000 \mathrm{mg}$; vitamin $\mathrm{B}_{1}$ : $3000 \mathrm{mg}$; vitamin $\mathrm{B}_{2}: 1000 \mathrm{mg}$; vitamin $\mathrm{B}_{6}: 6000 \mathrm{mg}$; vitamin $\mathrm{B}_{12}: 20000 \mathrm{mcg}$; vitamin C: $300 \mathrm{mg}$; niacin: $60000 \mathrm{mg}$; pantothenic acid: $20000 \mathrm{mg}$; biotin: $50 \mathrm{mg}$; folic acid: $1000 \mathrm{mg}$; selenium: $600 \mathrm{mg}$

${ }^{2}$ Warrant level per kg: Fe: 50000 mg; Co: 200 mg; Cu: 10000 mg; Zn: 60000 mg; Mn: 80000 mg; I: 1000 mg

${ }^{3}$ Banox: BHA. BHT. Propilgalato

AGP: antibiotic growth promoter

To determine the proportion (\%) of each egg component, the yolks were separated and weighed on a precision scale. The shells were washed, and dried at room temperature for 48 hours, and then weighed. The proportions of yolk and shell were obtained as the ratio between the weight of each portion and the egg weight, and the albumen was determined by difference: albumen $=100-($ yolk + shell). The yolks were evaluated with a visual comparison using the DSM colour fan, and an objective measurement based on the Minolta CR300 colorimeter (Tokyo, Japan), which operated in the CIE system ( $L^{*}, a^{\star}$, and $\left.b^{\star}\right)$, in which $L^{*}$ represents the lightness, $a^{*}$ is the red colour intensity, and $b^{*}$ is the yellow colour intensity. For this purpose, the measuring probe was placed in contact with the yolk surface one minute after the fresh egg was cracked. The device was calibrated with a white ceramic hob, adopting illuminant $D_{65}$. The shell thickness was 
regarded as the average of the thicknesses obtained in the three eggshell regions (apical, equatorial and basal), using a digital micrometre with $0.01 \mathrm{~mm}$ divisions.

Lipid peroxidation was evaluated by determining the thiobarbituric acid reactive substances (TBARS), utilizing the method of aqueous acid extraction with fresh yolks (Cherian et al., 2002). At the end of the experimental period, three eggs were collected per replicate, in which the yolks were separated from the albumen, placed in a beaker, homogenized, and analysed. The reactive substances in the sample were expressed in milligrams of malondialdehyde per kilogram of yolk.

After 10 weeks from the beginning of the trial, one collection of excreta was performed for microbiological analysis. Aluminium trays were coated with plastic canvas and placed under the cages for one hour, and the excreta was collected and packed in plastic bags, and immediately transported in a refrigerated cooler containing dry ice to laboratory analysis. For total mesophilic, faecal coliform and thermotolerant coliform counts, $25 \mathrm{~g}$ of each sample was transferred to an Erlenmeyer flask containing 225 $\mathrm{mL}$ of peptone water $1 \%$, resulting in the first dilution $\left(10^{-1}\right)$. From this dilution, serial dilutions were performed using the same proportion until dilution $10^{-8}$. For each dilution, an inoculum of $1.0 \mathrm{~mL}$ was added in the Petri dish for each group of microorganisms. Total mesophilic coliforms were counted on plate count agar (Difco, USA) and faecal coliforms in MacConkey agar (Difco, USA), both after aerobic bacteriological incubation at $37^{\circ} \mathrm{C}$ for 24 hours. The colony counts were expressed in colony-forming units (CFU) per gram of sample. For detection of Salmonella spp., the Erlenmeyer flasks containing the material that remained from previous analyses were incubated in bacteriological oven (pre-enrichment step). After that, $1 \mathrm{~mL}$ and $0.1 \mathrm{~mL}$ from each sample were transferred to tubes containing $10 \mathrm{~mL}$ tetrathionate broth, and RapapportVassiliadis broth, respectively, and incubated in a bacteriological incubator. After the incubation period, the samples were streaked on MacConkey agar (Difco, USA) and incubated. From each sample, 5 nonfermenting lactose colonies were selected and streaked in plates containing brilliant green agar, Hektoen agar and Salmonella-Shigella agar. Samples with suggestive growth of Salmonella spp. were introduced to tubes containing triple sugar iron agar and incubated. Samples with suggestive growth in tubes were selected for biochemical tests. The incubation was performed at $37^{\circ} \mathrm{C}$ for 24 hours for all stages.

Normality of residuals and homogeneity of variance tests were performed on raw data. For microbiological analysis, data were subjected to a transformation process $(\sqrt{x}+1)$ to achieve a normalized distribution. The data of all treatments were subjected to analysis of variance using PROC GLM in SAS (Statistical Analysis System, University Edition) according to a completely randomized design, and means were compared by the Student-Newman-Keuls test at $5 \%$ probability. Regression analysis was also performed, excluding the treatments without CNSL, to determine the best level of CNSL in the diets.

\section{Results}

No significant differences were observed among the treatments for any of the performance variables, which indicates that the inclusion of CNSL in the diet did not improve or compromise the performance of the laying hens, and neither did the addition of antibiotic growth promoter (Table 2). No significant effect of treatments was observed on the percentages of albumen, yolk, and shell, specific gravity, Haugh unit and shell thickness (Table 3).

Table 2 Means of feed intake, egg production, egg weight, egg mass and feed conversion ratio of laying hens fed diets with cashew nut shell liquid

\begin{tabular}{|c|c|c|c|c|c|c|c|c|c|c|}
\hline \multirow{2}{*}{ Variables } & \multirow{2}{*}{$\begin{array}{c}\text { Control } \\
\text { without } \\
\text { AGP }\end{array}$} & \multirow{2}{*}{$\begin{array}{c}\text { Control } \\
\text { with } \\
\text { AGP }\end{array}$} & \multicolumn{4}{|c|}{$\begin{array}{c}\text { Cashew nut shell liquid levels } \\
(\mathrm{g} / \mathrm{kg})\end{array}$} & \multirow{2}{*}{$\begin{array}{c}P \text { - } \\
\text { value }\end{array}$} & \multirow{2}{*}{$\mathbf{R}$} & \multirow{2}{*}{ SE } & \multirow{2}{*}{$\begin{array}{c}\mathrm{SE} \\
\text { regression }\end{array}$} \\
\hline & & & 2.5 & 5.0 & 7.5 & 10.0 & & & & \\
\hline Feed intake (g/kg) & 105.6 & 103.3 & 103.8 & 105.4 & 102.9 & 103.7 & 0.4727 & NS & 8.17 & 9.55 \\
\hline Egg production (\%) & 93.5 & 96.9 & 94.5 & 94.4 & 93.1 & 93.1 & 0.0863 & NS & 5.91 & 5.20 \\
\hline Egg weight (g) & 61.6 & 60.4 & 59.9 & 60.7 & 59.7 & 60.0 & 0.4240 & NS & 2.90 & 2.95 \\
\hline Egg mass (g/day) & 57.6 & 58.5 & 56.7 & 57.3 & 55.6 & 55.9 & 0.2093 & NS & 4.81 & 4.70 \\
\hline Feed conversion ( $\mathrm{g} / \mathrm{g}$ ) & 1.84 & 1.77 & 1.83 & 1.84 & 1.86 & 1.86 & 0.0608 & NS & 0.00 & 0.00 \\
\hline
\end{tabular}

AGP: antibiotic growth promoter; R: regression analysis; SE: standard error; NS: no significant effect $(P>0.05)$ 
Data of yolk colour, components of the yolk colour and TBARS values in egg yolk from the birds that were subjected to various levels of CNSL are shown in Table 3. By regression analysis, a quadratic effect considering the inclusion levels of CNSL was observed on yolk colour, measured by the DSM colour fan, the equation of which was $Y=7.052+0.213 X-0.017 X^{2}\left(R^{2}=0.69\right)$. According to the equation, the yolk colour increased initially, reaching its maximum level at $6.3 \mathrm{~g} / \mathrm{kg}$ of CNSL in the diet, and then it declined. A significant effect of treatments on the yolk colour was observed, with higher values for the treatments without the antibiotic growth promoter and with $7.5 \mathrm{~g} / \mathrm{kg}$ of CNSL in diet and lower for the treatment with antibiotic growth promoter. On the other hand, the colour component $a^{*}$ (red intensity) was higher in eggs from laying hens fed the diet with $5.0 \mathrm{~g} / \mathrm{kg}$ of CNSL, whereas the treatment with antibiotic growth promoter obtained the lowest value.

Table 3 Egg quality traits of laying hens fed diets with cashew nut shell liquid

\begin{tabular}{|c|c|c|c|c|c|c|c|c|c|c|}
\hline \multirow{2}{*}{ Variables } & \multirow{2}{*}{$\begin{array}{c}\text { Control } \\
\text { without } \\
\text { AGP }\end{array}$} & \multirow{2}{*}{$\begin{array}{c}\text { Control } \\
\text { with } \\
\text { AGP }\end{array}$} & \multicolumn{4}{|c|}{$\begin{array}{c}\text { Cashew nut shell liquid } \\
\text { levels }(\mathrm{g} / \mathrm{kg})\end{array}$} & \multirow{2}{*}{$\begin{array}{c}P \text { - } \\
\text { value }\end{array}$} & \multirow{2}{*}{$\mathbf{R}$} & \multirow{2}{*}{ SE } & \multirow{2}{*}{$\begin{array}{c}\mathrm{SE} \\
\text { regression }\end{array}$} \\
\hline & & & 2.5 & 5.0 & 7.5 & 10.0 & & & & \\
\hline Albumen percentage (\%) & 64.5 & 64.2 & 64.3 & 64.2 & 63.9 & 64.5 & 0.3411 & NS & 0.28 & 0.32 \\
\hline Yolk percentage (\%) & 26.1 & 26.3 & 26.0 & 26.3 & 26.4 & 25.9 & 0.4832 & NS & 0.25 & 0.33 \\
\hline Shell percentage (\%) & 9.4 & 9.5 & 9.7 & 9.5 & 9.7 & 9.6 & 0.0648 & NS & 0.04 & 0.05 \\
\hline Specific gravity $\left(\mathrm{g} / \mathrm{cm}^{3}\right)$ & 1.083 & 1.082 & 1.082 & 1.081 & 1.080 & 1.080 & 0.4076 & NS & 0.00 & 0.00 \\
\hline Haugh units & 80.4 & 78.7 & 80.2 & 79.8 & 82.2 & 81.1 & 0.1553 & NS & 4.80 & 6.07 \\
\hline Egg shell thickness (mm) & 0.31 & 0.32 & 0.32 & 0.32 & 0.33 & 0.33 & 0.1919 & NS & 0.00 & 0.00 \\
\hline
\end{tabular}

AGP: antibiotic growth promoter; R: regression analysis; SE: standard error; NS: no significant effect $(P>0.05)$

The antioxidant activity of anacardic acids with the response expressed by the stability of the yolk lipids, measured by TBARS, showed significant differences in the fresh egg yolk (Table 4). According to the regression analysis, a quadratic trend $\left(Y=1.297-0.152 X+0.013 X^{2}, R^{2}=0.80\right)$ with increasing levels of CNSL was observed on the TBARS values of the yolk. According to the equation, the TBARS values decreased based on the CNSL inclusion level, reaching their minimum at around $5.8 \mathrm{~g} / \mathrm{kg}$.

Table 4 Means of yolk colour, colour components, and thiobarbituric acid reactive substances values of egg yolk of laying hens fed diets with cashew nut shell liquid

\begin{tabular}{|c|c|c|c|c|c|c|c|c|c|c|}
\hline \multirow{2}{*}{ Variables } & \multirow{2}{*}{$\begin{array}{c}\text { Control } \\
\text { without } \\
\text { AGP }\end{array}$} & \multirow{2}{*}{$\begin{array}{c}\text { Control } \\
\text { with } \\
\text { AGP }\end{array}$} & \multicolumn{4}{|c|}{$\begin{array}{c}\text { Cashew nut shell liquid levels } \\
(\mathrm{g} / \mathrm{kg})\end{array}$} & \multirow[t]{2}{*}{$P$-value } & \multirow[t]{2}{*}{$\mathbf{R}$} & \multirow[t]{2}{*}{ SE } & \multirow{2}{*}{$\begin{array}{c}\mathrm{SE} \\
\text { regression }\end{array}$} \\
\hline & & & 2.5 & 5.0 & 7.5 & 10.0 & & & & \\
\hline Yolk colour $^{1}$ & $7.79^{\mathrm{a}}$ & $7.12^{\mathrm{C}}$ & $7.51 b$ & $7.59^{b}$ & $7.78^{\mathrm{a}}$ & $7.43^{b}$ & $<0.0001$ & $\mathrm{Q}^{*}$ & 0.02 & 0.04 \\
\hline$L^{*}$ & 77.0 & 77.7 & 75.8 & 75.9 & 76.8 & 74.9 & 0.2761 & NS & 2.73 & 2,79 \\
\hline$a^{*}$ & $3.10^{\mathrm{abc}}$ & $2.18^{\mathrm{c}}$ & $2.40^{\mathrm{bc}}$ & $4.30^{\mathrm{a}}$ & $3.60^{\mathrm{ab}}$ & $3.55^{\mathrm{ab}}$ & 0.0010 & NS & 0.40 & 0,45 \\
\hline$b^{*}$ & 68.2 & 67.8 & 66.4 & 67.0 & 69.1 & 66.1 & 0.0963 & NS & 2.48 & 2,44 \\
\hline TBARS (mg/kg) & $1.10^{\mathrm{a}}$ & $1.12^{\mathrm{a}}$ & $0.98^{\mathrm{ab}}$ & $0.93^{\mathrm{ab}}$ & $0.84^{b}$ & $1.12^{\mathrm{a}}$ & 0.0037 & $Q^{*}$ & 0.21 & 0,23 \\
\hline
\end{tabular}

AGP: antibiotic growth promoter; R: regression analysis; SE: standard error; NS: no significant effect $(P>0.05)$; Q: quadratic effect; TBARS: thiobarbituric acid reactive substances

Means followed by different superscripts within a row differ by the SNK (5\%) test

${ }^{1}$ DSM colour fan: $L^{\star}$ : darkness; $a^{\star}$ : red intensity; $b^{\star}$ : yellow intensity

In the comparison of means, the dietary level of $7.5 \mathrm{~g} / \mathrm{kg}$ of CNSL resulted in the lowest TBARS value, whereas the treatments with and without antibiotic growth promoter and the addition level of $10.0 \mathrm{~g} / \mathrm{kg}$ of CNSL in the diet resulted in the highest TBARS values in yolk. In terms of the higher inclusion CNSL level 
evaluated in the present work, the increase in the lipid oxidation of yolk may suggest a pro-oxidative effect of CNSL when higher concentrations are utilized.

For microbiological analysis, the presence of Salmonella spp. was not noted in any of the samples, indicating the absence of bacteria in the excreta and the microbiological quality of eggs by low microbiological contamination. For the other microorganisms, there was no significant effect of treatments on total mesophilic, total coliform and thermotolerant coliform counts on the excreta of laying hens (Table 5).

Table 5 Total mesophilic, total coliform and thermotolerant coliform count in excreta of laying hens fed diets with cashew nut shell liquid

\begin{tabular}{|c|c|c|c|c|c|c|c|c|c|c|}
\hline \multirow{2}{*}{ Variables } & \multirow{2}{*}{$\begin{array}{c}\text { Control } \\
\text { without } \\
\text { AGP }\end{array}$} & \multirow{2}{*}{$\begin{array}{c}\text { Control } \\
\text { with } \\
\text { AGP }\end{array}$} & \multicolumn{4}{|c|}{$\begin{array}{c}\text { Cashew nut shell liquid } \\
\text { levels, g/kg }\end{array}$} & \multirow{2}{*}{$\begin{array}{c}P- \\
\text { value }\end{array}$} & \multirow{2}{*}{$\mathbf{R}$} & \multirow{2}{*}{ SE } & \multirow{2}{*}{$\begin{array}{c}\mathrm{SE} \\
\text { regression }\end{array}$} \\
\hline & & & 2.5 & 5.0 & 7.5 & 10.0 & & & & \\
\hline Total mesophilic (CFU $10^{-3}$ ) & 1.96 & 5.52 & 4.04 & 1.31 & 4.94 & 3.04 & & & & \\
\hline $\begin{array}{l}\text { Total mesophilic } \\
\text { (transformated value) }\end{array}$ & 1.63 & 2.44 & 2.11 & 1.37 & 2.35 & 1.89 & 0.1226 & NS & 0.03 & 0.12 \\
\hline Total coliforms $\left(\mathrm{CFU} 10^{-3}\right)$ & 2.60 & 1.81 & 11.0 & 2.47 & 2.32 & 4.47 & & & & \\
\hline $\begin{array}{l}\text { Total coliforms (transformated } \\
\text { value) }\end{array}$ & 1.85 & 1.62 & 2.94 & 1.77 & 1.79 & 2.26 & 0.3124 & NS & 0.57 & 0.63 \\
\hline $\begin{array}{l}\text { Thermotolerant coliforms } \\
\left(\mathrm{CFU} 10^{-3}\right)\end{array}$ & 1.10 & 1.30 & 2.53 & 2.52 & 1.37 & 3.62 & & & & \\
\hline $\begin{array}{l}\text { Thermotolerant coliforms } \\
\text { (transformated value) }\end{array}$ & 1.44 & 1.45 & 1.83 & 1.78 & 1.51 & 2.10 & 0.1284 & NS & 0.08 & 0.14 \\
\hline
\end{tabular}

AGP: antibiotic growth promoter; R: regression analysis; SE: standard error; NS: no significant effect $(P>0.05)$

\section{Discussion}

The performance data that were obtained in the present study can be viewed as indicative that CNSL in laying hen diets does not affect egg production, and there was no evidence of toxicity of their compounds up to the maximum level that was assessed. Besides, up to the level of $10 \mathrm{~g} / \mathrm{kg}$, it did not affect the palatability of the diet or feed intake. These results corroborate those of Odunsi \& Oyewole (1996), who observed that the addition up to $10 \mathrm{~g} / \mathrm{kg}$ of CNSL did not affect the performance of broilers during the starter phase, but higher levels resulted in lower feed intake and daily weight gain. On the other hand, the lack of effects on performance of birds from treatment without growth promoters (Table 2) indicates that the birds did not undergo any health challenge that might have affected their performance, which made it difficult to detect a possible response of these birds to one of the beneficial biological actions of CNSL. According to Cromwell (1991), the beneficial effect of antibiotic growth promoter is noted in field conditions, with responses twice as high as those observed in experimental stations because of the differences in sanitation, stress conditions and the higher probability of disease occurrence. Thus, some researchers (Jang et al., 2004; López et al., 2012) attributed the lack of variation on performance in trials that evaulated organic acids to the good nutrition and environmental conditions to which these birds were subjected. Moreover, the inconsistent results of studies that evaluated organic acids may be related to their characteristics and the need to modulate the level of each acid or blending in view of the varying conditions in which birds may be reared.

In relation to the compounds in CNSL, it is verified that anacardic acid has an effect on coccidiosis. Toyomizu et al. (2003) evaluated various levels of anacardic acid and CNSL in broiler chickens that were submitted to oral inoculation with Eimeria tenella oocysts and observed a reduction in the severity of caecal lesions during experimental infection. Murakami et al. (2014) also observed the effect of adding a mixture of functional oils containing CNSL in increasing the relationship of villus height to crypt depth ratio of the jejunum and increased dietary metabolizable energy in birds subjected to challenges with Eimeria acervulina, Eimeria maxima and Eimeria tenella. Thus, this could emphasize the importance of research with CNSL as a source of anacardic acid in the feeding of laying hens on their performance variables, considering mainly the challenges faced in poultry breeding.

Cashew nut shell liquid in the diet did not lead to changes in egg quality. Protein, amino acids and linoleic acid are usually the most important nutritional factors that affect egg weight, and are related directly to the proportion of egg components (Leeson \& Summers, 1997). Therefore, since that the basal diet that was utilized in the present work was formulated to be isonutritive, it can be suggested that the energy and 
nutrients consumed by birds were sufficient to maintain the same quality of eggs. On the other hand, it can be assumed that CNSL did not influence the digestibility of nutrients.

Many previous studies demonstrated that the use of organic acids, essential oils and plant extracts as additives to laying hen diets resulted in different effects on egg quality. Soltan (2008), and Özek et al. (2011) observed an improvement in some internal egg quality and shell parameters with the addition of organic acid to laying hen diets. However, some studies reported no benefits from the addition of these acids (Yesilbag \& Çolpan, 2006; Kaya et al., 2013) or plant extracts (Botsoglou et al., 2005; Florou-Paneri et al., 2005) on these variables. These contradictory results may be because of the supplementation level of the organic acid, essential oil or plant extract, and the source from which it is extracted.

Yolk colour has economic relevance because it is associated with nutritional quality. Consumers usually associate yolk colour with the number of vitamins. Corn is the feedstuff that is included in higher amounts in poultry diets and is also the main source of carotenoids, which are pigments that provide the yellow colour of the egg yolk. However, CNSL has been reported as being a dark reddish-brown liquid with the intensity of its colouration because of the presence of pigments (Sivakumar et al., 2014). Thus, the pigments in CNSL contributed to the increase in yolk colour and the greater proportion of the redness component $\left(a^{*}\right)$.

Several studies reported that the addition of organic acids to the diets of laying hen did not affect the yolk colour (Yesilbag \& Çolpan, 2006; Park et al., 2009). However, natural additives may change the yolk colour, as they may contain pigments that can be deposited in the yolk or even have compounds that can protect against the oxidative process. Accordingly, Abreu et al. (2014) found that the direct addition of 150 $\mathrm{mg} / \mathrm{kg}$ of anacardic acid to egg yolks that were subjected to drying resulted in greater values of yellowness owing to its antioxidant action, which caused a delay in the oxidation of carotenoid pigments.

The analysis of thiobarbituric acid reactive substances (TBARS) is one of the most commonly adopted methods to determine the oxidative rancidity of foods (Esterbauer, 1993). It measures the formation of secondary products of oxidation, especially malondialdehyde, which can contribute to the generation of smell and taste of oxidized fat (Kanatt et al., 2010; Lee et al., 2011). The concentration of TBARS may be a result of the ingestion of these substances from the diet and the subsequent transfer to the yolk, or even a consequence of the endogenous production of these substances by the birds (Radwan et al., 2008). Thus, the TBARS level in the eggs is related directly to the dietary lipid composition and to the transfer of antioxidant to the egg (Shahryar et al., 2010). Therefore, these results suggest a protective action of the antioxidants that are present in the CNSL on fresh eggs, demonstrating that the incorporation of natural antioxidants to laying hen diets could provide an improvement in the lipid oxidation of egg yolk. In the literature, many studies evaluated the addition of various compounds with antioxidant action to the feed of laying hens, and consequent better oxidative stability of yolk (Botsoglou et al., 2005; Radwan et al., 2008; Zhao et al., 2011). However, in relation to the compounds that are present in the CNSL, Abreu et al. (2014) observed that the direct addition of $150 \mathrm{mg} / \mathrm{kg}$ of anacardic acid in egg yolk subjected to spray drying reduced the oxidation associated with the drying and storage process for up to 180 days.

Given that the use of growth promoters and CNSL aims to inhibit the development of pathogenic microbial flora in the gastrointestinal tract of laying hens, and that there was no difference in the microbiological analysis in the excreta of birds fed the control diet without these additives, in relation to those fed the diet that contained growth promoter and CNSL, it can be suggested that the absence of response may be an indication of a minor health challenge in the experimental environment.

Although the results indicated that the use of CNSL in the diet was not able to improve the performance of the laying hens and the egg quality parameters, positive effects of CNSL were observed in the yolk colour and egg oxidative stability. So, new studies should be conducted to evaluate CNSL as a natural additive to poultry feeding, since the action of this additive to benefit animal health and performance depends on the level of challenge to which this animal is subjected in the field.

\section{Conclusion}

It can be concluded that the addition up to $10.0 \mathrm{~g} / \mathrm{kg}$ of CNSL as source of anacardic acid in laying hen diet does not influence their performance or egg quality. However, it was found that the level of $7.5 \mathrm{~g} / \mathrm{kg}$ of CNSL is effective in reducing lipid oxidation and improving the colour of the yolk.

\section{Acknowledgments}

The authors thank to CAPES (Coordenação de Aperfeiçoamento de Pessoal de Nível Superior), FUNCAP (Fundação Cearense de Apoio ao Desenvolvimento Científico e Tecnológico) and CNPq (Conselho Nacional de Desenvolvimento Científico e Tecnológico) for financial support. The authors also thank T. Oliveira for allowing the use of the Laboratory of Plant Defence Proteins for the enzymatic analyses, and E.M.C. Silva for allowing the use of the Laboratory of Meats and Fish for TBARS analyses. 


\section{Authors' Contributions}

ERF and PHW were responsible for project management, while MTST and RPRS assisted in laboratory assessment of biological samples. NMB, CEBC and NNPF were involved in data collection and laboratory work. NMB, ERF and PHW were responsible for writing revisions.

\section{Conflict of Interest Declaration}

None of the authors declare any competing interests.

\section{References}

Abreu, V.K.G., Pereira, A.L.F., Freitas, E.R., Trevisan, M.T.S. \& Costa, J.M.C., 2014. Effect of anacardic acid on oxidative and color stability of spray dried egg yolk. LWT - Food Sci. Technol. 55, 446-471.

Botsoglou, N., Florou-Paneri, P., Botsoglou, E., Dotas, V., Giannenas, I., Koidis, A. \& Mitrakos, P., 2005. The effect of feeding rosemary, oregano, saffron and a-tocopheryl acetate on hen performance and oxidative stability of eggs. S. Afr. J. Anim. Sci. 35, 143-151.

Cerqueira, F.M., Medeiros, M.H.G. \& Augusto, O., 2007. Antioxidantes dietéticos: Controvérsias e perspectivas. Quím. Nova. 30, 441-449 (in Portuguese, English abstract).

Cherian, G., Holsonbake, T.B., Goeger, M.P. \& Bildfell, R., 2002. Dietary conjugated linoleic acid alters yolk and tissue fatty acid composition and hepatic histopathology of laying hens. Lipids 37, 751-757.

Cromwell, G.L., 1991. Antimicrobial agents. In: E.R. Miller, D.E Ullrey \& A.J. Lewis (eds). Swine nutrition. ButterworthHeinemann, Stoneham, MA, USA. pp. 297-314.

Esterbauer, H., 1993. Cytotoxicity and genotoxicity of lipidoxidation products. Am. J. Clin. Nutr. 57, 779-785.

Florou-Paneri, P., Nikolakakis, I., Giannenas, I., Koidis, A., Botsoglou, E., Dotas, V. \& Mitsopoulos, I., 2005. Hen performance and egg quality as affected by dietary oregano essential oil and a-tocopheryl acetate supplementation. Int. J. Poult. Sci. 4, 449-454.

Himejima, M. \& Kubo, I., 1991. Antibacterial agents from the cashew Anacardium occidentale (Anacardiaceae) nut shell oil. J. Agric. Food Chem. 39, 418-421.

Hisex. Nutrition Management Guide. No date. Available at https://www.hisex.com/en/product/hisex-white/ Accessed 7 August 2013.

Jang, I.S., Ko, Y.H., Yang, H.Y., Ha, J.S., Kim, J.Y., Kim, J.Y., Kang, S.Y., Yoo, D.H., Nam, D.S., Kim, D.H. \& Lee, C.Y., 2004. Influence of essential oil components on growth performance and the functional activity of the pancreas and small intestine in broiler chickens. Asian-Austral. J. Anim. Sci. 17, 394-400.

Kanatt, S.R., Chander, R. \& Sharma, A., 2010. Antioxidant and antimicrobial activity of pomegranate peel extract improves the shelf life of chicken products. Int. J. Food Sci. Technol. 45, 216-222.

Kaya, H., Kaya, A., Gul, M. \& Celeb, S., 2013. The effect of zeolite and organic acid mixture supplementation in the layer diet on performance, egg quality traits and some blood parameters. J. Anim. Vet. Adv. 12, 782-787.

Lee, M.A., Choi, J.H., Choi, Y.S., Kim, H.Y., Kim, H.W., Hwang, K.E., Chung, H.K. \& Kim, C.J., 2011. Effects of kimchi ethanolic extracts on oxidative stability of refrigerated cooked pork. Meat Sci. 89, 405-411.

Leeson, S. \& Summers, J.D., 1997. Commercial poultry nutrition. 2nd edition. University Books, Ontario, Toronto, Canada.

López, C.A.A., Lima, K.R.S., Manno, M.C., Tavares, F.B., Fernandes Neto, D.L., Jesus, M.L.C. \& Viana, M.A.O., 2012. Effects of cashew nut shell liquid (CNSL) on the performance of broiler chickens. Arq. Bras. Med. Vet. Zootec. 64, 1027-1035 (in Portuguese, English abstract).

Mazzetto, S.E., Lomonaco, D. \& Mele, G., 2009. Óleo da castanha de caju: oportunidades e desafios no contexto do desenvolvimento e sustentabilidade industrial. Quím. Nova 32, 732-741 (in Portuguese, English abstract).

Muniz, C.R., Freire, F.C.O., Lemos, E.H., Pinto, G.A.S., Figueiredo, E.A.T. \& Figueiredo, R.W., 2006. Effect of processing conditions on the microbiological quality of cashew nuts. Braz. J. Food Technol. 9, 33-38.

Murakami, A.E., Eyng, C. \& Torrent, J., 2014. Effects of functional oils on coccidiosis and apparent metabolizable energy in broiler chickens. Asian-Austral. J. Anim. Sci. 27, 981-989.

Odunsi, A.A. \& Oyewole, S.O., 1996. Response of broiler chicks to diets containing varying levels of cashew nut oil and palm oil. Ghana J. Agric. Sci. 29, 59-63.

Özek, K., Wellmann, K.T., Ertekin, B. \& Tarim, B., 2011. Effects of dietary herbal essential oil mixture and organic acid preparation on laying traits, gastrointestinal tract characteristics, blood parameters and immune response of laying in a hot summer season. J. Anim. Feed Sci. 20, 575-586.

Park, K.W., Rhee, A.R., Um, J.S. \& Paik, I.K., 2009. Effect of dietary available phosphorus and organic acids on the performance and egg quality of laying hens. J. Appl. Poult. Res. 18, 598-604.

Radwan, L.N., Hassan, R.A., Qota, E.M. \& Fayek, H.M., 2008. Effect of natural antioxidant on oxidative stability of eggs and productive and reproductive performance of laying hens. Int. J. Poult. Sci. 7, 134-150.

Shahryar, H.A., Salamatdoust, R., Chekani-Azar, S., Ahadi, F. \& Vahdatpoor, T., 2010. Lipid oxidation in fresh and stored eggs enriched with dietary ômega 3 and ômega 6 polyunsaturated fatty acids and vitamin $E$ and $A$ dosages. Afr. J. Biotechnol. 9, 1827-1832.

Sikora, E., Cieslik, E., Leszczynska, T., Filipiak-Florkiwuacz, A. \& Pisulewski, P.M., 2008. The antioxidant activity of selected cruciferous vegetables subjected to aquathermal processing. Food Chem. 107, 50-55.

Silva, M.L.C., Costa, R.S., Santana, A.S. \& Koblitz, M.G.B., 2010. Compostos fenólicos, carotenóides e atividade antioxidante em produtos vegetais. Semina: Ciênc. Agrár. 31, 669-682. (in Portuguese, English abstract). 
Sivakumar, S., Venkatachalam, R., Nedunchezhian, N., Sivakumar, P. \& Rajendran, P., 2014. Processing of cashew nut shell and feasibility of its oil as bio fuel in compression ignition. J. Chem. Pharm. Sci. 4, 133-135.

Soltan, M., 2008. Effect of dietary organic acid supplementation on egg production, egg quality and some blood serum parameters in laying hens. Int. J. Poult. Sci. 7, 613-621.

Toyomizu, M., Nakai, Y., Nakatsu, T. \& Akiba, Y., 2003. Inhibitory effect of dietary anacardic acid supplementation on cecal lesion formation following chicken infection. Anim. Sci. J. 74, 105-109.

Toyomizu, M., Okamoto, M., Ishibashi, T., Chen, Z. \& Nakatsu, T., 2000. Uncoupling effect of anacardic acids from cashew nut shell oil on oxidative phosphorylation of rat liver mitochondria. Life Sci. 66, 229-234.

Trevisan, M.T.S., Pfundstein, B., Haubner, R., Würtele, G., Spiegelhalder, B., Bartsch, H. \& Owen, R.W., 2006. Characterization of alkyl phenols in cashew (Anacardium occidentale) products and assay of their antioxidant capacity. Food Chem. Toxicol. 44, 188-197.

Yesilbag, D. \& Çolpan, I., 2006. Effects of organic acid supplemented diets on growth performance, egg production and quality and on serum parameters in laying hens. Rev. Med. Vet. 157, 280-284.

Zhao, X., Yang, Z.B., Yang, W.R., Wang, Y., Jiang, S.Z. \& Zhang, G.G., 2011. Effects of ginger root (Zingiber officinale) on laying performance and antioxidant status of laying hens and on dietary oxidation stability. Poult. Sci. 90, $1720-1727$. 